DOI: $10.4274 /$ jarem.galenos.2021.3947

J Acad Res Med 2021;11(2):143-8

\title{
Relationship Between the Levels of 25-hydroxyvitamin D at Presentation and the Clinical, Laboratory and Follow-up Data of Children and Adolescents with Type-1 Diabetes Mellitus
}

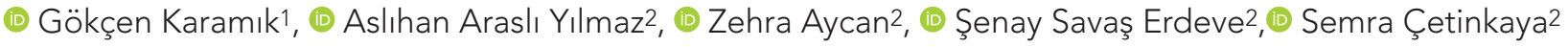 \\ ${ }^{1}$ University of Health Sciences Turkey, Dr. Sami Ulus Gynecology Obstetrics and Child Health and Diseases Training and Research Hospital, \\ Clinic of Pediatrics, Ankara, Turkey \\ 2University of Health Sciences Turkey, Dr. Sami Ulus Gynecology Obstetrics and Child Health and Diseases Training and Research Hospital, \\ Clinic of Pediatric Endocrinology, Ankara, Turkey
}

Cite this article as: Karamık G, Araslı Yılmaz A, Aycan Z, Savaş Erdeve Ş, Çetinkaya S. Relationship Between the Levels of 25-hydroxyvitamin D at Presentation and the Clinical, Laboratory and Follow-up Data of Children and Adolescents with Type-1 Diabetes Mellitus. J Acad Res Med 2021;11(2):143-8

\begin{abstract}
Objective: This study aimed to assess the relationship of 25-hydroxyvitamin $\mathrm{D}[25(\mathrm{OH}) \mathrm{D}]$ levels at presentation with the clinical, laboratory and followup data of children and adolescents with type-1 diabetes mellitus.

Methods: Patients who had available follow-up data and were diagnosed to have type-1 diabetes mellitus in our clinic between 2009 and 2015 were included. Patient files were screened for data regarding presentation, history/family history and clinical, laboratory and follow-up data. Data were also assessed in the context of threshold values for sufficiency, insufficiency or deficiency of 25(OH)D.

Results: The mean age was $8.62 \pm 14.19$ years. Type-1 diabetes mellitus was diagnosed as diabetic ketoacidosis in $53.9 \%$ of the patients. The mean $25(\mathrm{OH}) \mathrm{D}$ level was $18.90 \pm 11.07 \mathrm{ng} / \mathrm{mL}$ at the time of diagnosis. The mean time to subcutaneous insulin therapy through the resolution of ketosis/ diabetic ketoacidosis in the group with vitamin $D$ deficiency was significantly longer than vitamin $D$ insufficient and sufficient groups ( $p=0.020$ ). The mean 25(OH)D levels were lower in patients diagnosed with moderate and severe diabetic ketoacidosis $(p=0.020)$. Insulin doses at discharge were significantly lower in patients with a mean $25(\mathrm{OH}) \mathrm{D}$ level of $10-20 \mathrm{ng} / \mathrm{mL}(\mathrm{p}=0.039)$. The relationship of vitamin $\mathrm{D}$ groups with $\mathrm{HbA} 1 \mathrm{c}$ and insulin doses in the follow-up period was not significant.

Conclusion: This pilot study assessed the clinical, laboratory and follow-up data and the honeymoon status on month $2( \pm 1)$. We found that 25(OH)D levels affected clinical features at the time of diagnosis but not during follow-up.

Keywords: 25-hydroxyvitamin D, type-1 diabetes mellitus, children, adolescence, ketoacidosis
\end{abstract}

ORCID IDs of the authors: G.K. 0000-0002-8678-1666; A.A.Y. 0000-0003-4403-2381; Z.A. 0000-0003-4584-2976; Ş.S.E. 0000-0002-4164-5089; S.Ç. 0000-0003-3974-2872. 


\section{INTRODUCTION}

Type-1 diabetes mellitus (T1DM) is an autoimmune disorder whose incidence increases because of beta cell destruction. Its pathogenesis involves autoimmunity, genetics and environmental factors. Although the causes of T1DM have not been fully elucidated, genetic factors in human leucocyteantigen complexes and environmental factors, such as diet or viral infections, are likely implicated in the T1DM pathogenesis (1). The incidence of autoimmune disorders, such as multiple sclerosis, inflammatory bowel disease, rheumatoid arthritis and T1DM, is high in northern countries, and the frequency of vitamin $D$ deficiency in people living in these countries is high; as such, vitamin $D$ is highly related to the immune system and autoimmune disorders. The EURODIAB Work Group reported that the risk of T1DM development decreases by $33 \%$ in children who receive vitamin $D$ supplementation compared with those who have no supplementation (2). Type-1 helper, type-2 helper and regulatory T-cells participate in the interaction between vitamin $D$ and the immune system. Vitamin $D$ may slow down the process of autoimmune insulitis in T1DM $(3,4)$.

Our study aimed to assess the relationship of 25-hydroxyvitamin $D[25(\mathrm{OH}) \mathrm{D}]$ levels at presentation with the clinical, laboratory and follow-up data of children and adolescents with T1DM. We also determined the effects of vitamin D on the T1DM pathogenesis.

\section{METHODS}

\section{Study Population}

Dr. Sami Ulus Gynecology Obstetrics and Child Health and Diseases Training and Research Hospital Ethics Committee ethical approval was obtained for the retrospective review of the cohort of patients diagnosed with T1DM (approval number: 2016/73799008). A total of 115 patients who had positive diabetes-associated autoantibodies and were diagnosed with T1DM in accordance with the 2014 American Diabetes Association Diabetes Mellitus Diagnosis and Classification criteria between 2009 and 2015 were included. Their 25(OH) $\mathrm{D}$ levels were measured at presentation, and their follow-up data were collected for at least 2 years. The following data were extracted from patient records: Age, gender, physical examination and laboratory findings at presentation, diagnosis at presentation (hyperglycaemia, ketosis and ketoacidosis), time to the resolution of ketoacidosis, insulin doses at discharge (U/ $\mathrm{kg} /$ day), insulin doses and honeymoon status in the first control visit (on month $2 \pm 1$ ), mean insulin doses per year during followup and $\mathrm{HbA} 1 \mathrm{c}$ levels.

\section{Acquisition and Definition of Data}

Diabetic ketoacidosis (DKA) was diagnosed on the basis of the following criteria (5): Plasma glucose level $\geq 200 \mathrm{mg} / \mathrm{dL}$, venous $\mathrm{pH}<7.3$ or $\mathrm{HCO}_{3}<15 \mathrm{mEq} / \mathrm{L}$ and total ketone bodies $>5 \mathrm{mmol} / \mathrm{L}$. DKA was classified according to $\mathrm{pH}$ and $\mathrm{HCO}_{3}$ as follows (6): Mild DKA, $\mathrm{pH}<7.3$ and $\mathrm{HCO}_{3}<15 \mathrm{mmol} / \mathrm{L}$; moderate
DKA, $\mathrm{pH}<7.2$ and $\mathrm{HCO}_{3}<10 \mathrm{mmol} / \mathrm{L}$; and severe $\mathrm{DKA}, \mathrm{pH}<7.1$ and $\mathrm{HCO}_{3}<5 \mathrm{mmol} / \mathrm{L}$.

Metabolic control was assessed in terms of mean insulin doses per year, which was the arithmetic mean of $\mathrm{HbA} 1 \mathrm{c}$ levels measured at 3-month interval during follow-up: $\mathrm{HbA} 1 \mathrm{c}<7.5 \%$, good metabolic control; 7.6-9\%, moderate metabolic control; and $>9.1 \%$, poor metabolic control (7). Honeymoon status was defined as an insulin requirement of $<0.5 \mathrm{U} / \mathrm{kg} /$ day in the first control visit (on month 2ะ1) (8).

Serum 25(OH)D levels were measured and classified as follows: Deficient, <20 ng/mL; insufficient, 21-29 ng/mL; and sufficient, $>30 \mathrm{ng} / \mathrm{mL}(9,10)$. All the patients were initially given $2000 \mathrm{IU} /$ day vitamin D3 replacement therapy for 6 weeks at discharge. After the supplementation therapy, our patients were prescribed to have $1000 \mathrm{IU} /$ day vitamin D. The relationship of $25(\mathrm{OH}) \mathrm{D}$ level with T1DM clinical features at the time of diagnosis and follow-up data was investigated.

\section{Statistical Analysis}

Data were analysed by using SPSS version 15.0 and expressed as $n(\%)$, mean \pm standard deviation (SD) or median (minimummaximum) as appropriate. SD scores (SDS) were calculated by subtracting the patient's value from the mean value of that age and dividing by the SD value determined for that age. A chisquare test was conducted to assess the relationship between two categorical variables. Clinical and laboratory values were given as descriptive statistics. Student's $t$ and Mann-Whitney $U$ tests were performed to compare parametric and non-parametric data. For quantitative data, One-Way ANOVA was carried out to compare categorical variables with three or more categories in case of normal distribution. Kruskal-Wallis test was used in case of skewed distribution. Results with $\mathrm{p}<0.05$ were considered statistically significant.

\section{RESULTS}

A total of 115 children and adolescents with T1DM were included in this study. T1DM was diagnosed in the prepubertal period of $59.1 \%$ of the patients. The mean age was $8.62 \pm 4.19$ years, whilst most patients (41.9\%) were 10-14 years old. Of the patients, $53.9 \%$ were girls. The patients' demographics and laboratory data are summarised in Table 1. The mean body weight, height and body mass index-SDS values were found to be normal at the time of presentation, in the first control visit (on month $2 \pm 1$ ) and in the final control visit. However, the lowest values were detected at the time of presentation. The mean $25(\mathrm{OH}) \mathrm{D}$ level was lower in girls than in boys $(p=0.020)$ The phosphor and alkaline phosphatase (ALP) levels were lower in girls than in boys. However, age-adjusted ALP levels were within normal ranges in all cases.

A comorbid autoimmune disorder was detected in $23.4 \%$ of the patients (including Hashimoto thyroiditis in 18 cases and celiac disease in 8 cases). When autoantibodies were considered, positive anti-islet antibodies were found in $72.1 \%$ of the patients, positive anti-glutamic acid decarboxylase (anti-GAD) antibodies 
DKA in the deficient, insufficient and sufficient groups were $36.8 \%$, $33.3 \%$ and $44.4 \%$, respectively $(p=0.314)$.

The following results of the mean time to subcutaneous insulin therapy via the resolution of ketosis/DKA were found: $16.89 \mathrm{~h}$ (range: $4-53 \mathrm{~h}$ ) in the group with vitamin D deficiency, $9.70 \mathrm{~h}$ (range $1-20 \mathrm{~h}$ ) in the group with vitamin D insufficiency and $13.21 \mathrm{~h}$ (range 3-36 h) in the group with sufficient vitamin D levels. This parameter was significantly longer in the group with vitamin $D$ deficiency than vitamin $D$ insufficient and sufficient groups $(p=0.020)$. No significant relationship was observed between vitamin $D$ groups and follow-up data (Table 3).

The mean $25(\mathrm{OH}) \mathrm{D}$ level was $17.68 \mathrm{ng} / \mathrm{mL}$ in patients in the honeymoon phase in the first control visit (on month $2 \pm 1$ ). In cases without honeymoon status, the mean 25(OH)D level was $20.34 \mathrm{ng} /$ $\mathrm{mL}$, which was not significantly different from that of the patients in the honeymoon phase $(p=0.213)$. Vitamin $D$ replacement was given to the patients with a low 25(OH)D level. The assessment of the mean $25(\mathrm{OH}) \mathrm{D}$ levels in the metabolic control groups and sufficient groups, respectively. Additionally, the rates of severe

\section{Table 1. Patients' anthropometric measurements and laboratory data at presentation}

\begin{tabular}{|c|c|c|c|c|}
\hline & $\begin{array}{l}\text { Total } \\
(n=115)\end{array}$ & $\begin{array}{l}\text { Girl } \\
(n=62)\end{array}$ & $\begin{array}{l}\text { Boy } \\
(n=53)\end{array}$ & $p$ value \\
\hline $\begin{array}{l}\text { Weight-SDS, mean, } \\
\text { (min-max) }\end{array}$ & $\begin{array}{l}-0.49 \pm 1.18 \\
{[-3.50-(+2.88)]}\end{array}$ & $\begin{array}{l}-0.63 \pm 1.24 \\
{[-3.50-(+2.05)]}\end{array}$ & $\begin{array}{l}-0.32 \pm 1.08 \\
{[-2.92-(+2.88)]}\end{array}$ & 0.154 \\
\hline $\begin{array}{l}\text { Height-SDS, mean, } \\
\text { (min-max) }\end{array}$ & $\begin{array}{l}-0.02 \pm 1.16 \\
{[-3.05-(+3.18)]}\end{array}$ & $\begin{array}{l}-0.07 \pm 1.15 \\
{[-3.05-(+3.18)]}\end{array}$ & $\begin{array}{l}0.14 \pm 1.17 \\
{[-2.95-(+2.26)]}\end{array}$ & 0.328 \\
\hline $\begin{array}{l}\text { BMI-SDS, mean, } \\
\text { (min-max) }\end{array}$ & $\begin{array}{l}-0.75 \pm 1.41 \\
{[-6.20-(+3.16)]}\end{array}$ & $\begin{array}{l}-0.88 \pm 1.54 \\
{[-6.20-(+1.89)]}\end{array}$ & $\begin{array}{l}-0.60 \pm 1.24 \\
{[-3.83-(+3.16)]}\end{array}$ & 0.287 \\
\hline Pre-puberty, n (\%) & 68 (59.1\%) & $41(\% 66.1)$ & $27(\% 50.9)$ & \multirow{2}{*}{0.102} \\
\hline Puberty, n, (\%) & 47 (40.9\%) & $21(\% 33.9)$ & $26(\% 49.1)$ & \\
\hline 25(OH)D, ng/mL, mean, (min-max) & $\begin{array}{l}18.90 \pm 11.07 \\
(3.00-61.00)\end{array}$ & $\begin{array}{l}15.98 \pm 10.16 \\
(3.00-60.00)\end{array}$ & $\begin{array}{l}22.32 \pm 11.21 \\
(6.90-61.00)\end{array}$ & $0.020^{*}$ \\
\hline $\begin{array}{l}\text { Glucose, mg/dL, mean, } \\
\text { (min-max) }\end{array}$ & $\begin{array}{l}412.96 \pm 162.88 \\
(106-855)\end{array}$ & $\begin{array}{l}404.69 \pm 160.37 \\
(106-780)\end{array}$ & $\begin{array}{l}422.62 \pm 166.77 \\
(118-855)\end{array}$ & 0.560 \\
\hline $\begin{array}{l}\text { C-peptide, ng/mL, mean, } \\
\text { (min-max) }\end{array}$ & $\begin{array}{l}0.55 \pm 0.62 \\
(0.03-3.60)\end{array}$ & $\begin{array}{l}0.56 \pm 0.70 \\
(0.03-3.60)\end{array}$ & $\begin{array}{l}0.54 \pm 0.51 \\
(0.07-2.44)\end{array}$ & 0.880 \\
\hline $\begin{array}{l}\mathrm{HbA} 1 c, \%, \text { mean, } \\
\text { (min-max) }\end{array}$ & $\begin{array}{l}12.11 \pm 2.36 \\
(5.20-16.40)\end{array}$ & $\begin{array}{l}12.32 \pm 2.41 \\
(5.20-16.40)\end{array}$ & $\begin{array}{l}11.87 \pm 2.30 \\
(5.50-16.10)\end{array}$ & 0.310 \\
\hline $\begin{array}{l}\mathrm{pH} \text {, mean, } \\
\text { (min-max) }\end{array}$ & $\begin{array}{l}7.23 \pm 0.16 \\
(6.70-7.55)\end{array}$ & $\begin{array}{l}7.21 \pm 0.16 \\
(6.70-7.55)\end{array}$ & $\begin{array}{l}7.26 \pm 0.14 \\
(6.93-7.48)\end{array}$ & 0.106 \\
\hline $\begin{array}{l}\mathrm{HCO}_{3}, \mathrm{mmol} / \mathrm{lt} \text {, mean, } \\
\text { (min-max) }\end{array}$ & $\begin{array}{l}12.83 \pm 7.54 \\
(0.60-29.00)\end{array}$ & $\begin{array}{l}11.90 \pm 7.67 \\
(1.10-29.00)\end{array}$ & $\begin{array}{l}13.92 \pm 7.30 \\
(0.60-29.00)\end{array}$ & 0.152 \\
\hline $\begin{array}{l}\text { Calcium, mg/dL, mean, } \\
\text { (min-max) }\end{array}$ & $\begin{array}{l}9.65 \pm 0.46 \\
(8.40-10.70)\end{array}$ & $\begin{array}{l}9.59 \pm 0.49 \\
(8.40-10.70)\end{array}$ & $\begin{array}{l}9.71 \pm 0.43 \\
(8.80-10.50)\end{array}$ & 0.200 \\
\hline $\begin{array}{l}\text { Phosphor, mg/dL, mean, } \\
\text { (min-max) }\end{array}$ & $\begin{array}{l}4.19 \pm 1.11 \\
(1.40-8.80)\end{array}$ & $\begin{array}{l}3.87 \pm 0.93 \\
(2.20-6.20)\end{array}$ & $\begin{array}{l}4.54 \pm 1.19 \\
(1.40-8.80)\end{array}$ & $0.010^{*}$ \\
\hline Alkaline phosphatase, U/Lt, mean, (min-max) & $\begin{array}{l}262.74 \pm 113.39 \\
(117-840)\end{array}$ & $\begin{array}{l}241.42 \pm 81.79 \\
(117-483)\end{array}$ & $\begin{array}{l}288.94 \pm 139.55 \\
(121-840)\end{array}$ & $0.040^{*}$ \\
\hline $\begin{array}{l}\text { Albumin, g/dL, mean, } \\
\text { (min-max) }\end{array}$ & $\begin{array}{l}4.31 \pm 0.42 \\
(3.20-5.40)\end{array}$ & $\begin{array}{l}4.27 \pm 0.43 \\
(3.20-5.10)\end{array}$ & $\begin{array}{l}4.35 \pm 0.40 \\
(3.40-5.40)\end{array}$ & 0.306 \\
\hline $\begin{array}{l}\text { TSH, } \mu \mathrm{IU} / \mathrm{mL} \text {, mean, } \\
\text { (min-max) }\end{array}$ & $\begin{array}{l}2.35 \pm 2.36 \\
(0.46-23.60)\end{array}$ & $\begin{array}{l}2.31 \pm 1.47 \\
(0.46-7.55)\end{array}$ & $\begin{array}{l}2.39 \pm 3.11 \\
(0.62-23.60)\end{array}$ & 0.865 \\
\hline
\end{tabular}


stratified according to the mean $\mathrm{HbA} 1 \mathrm{c}$ level in the $1^{\text {st }}$ and $2^{\text {nd }}$ years revealed no significant differences amongst the groups ( $p=0.784$ and $p=0.834$ ).

After the patients with acidosis were stratified according to $25(\mathrm{OH}) \mathrm{D}$ levels, the mean 25(OH)D levels were lower in the patients diagnosed with moderate and severe DKA $(p=0.020$; Table 4).

In the patients stratified into two groups according to their $25(\mathrm{OH})$ $D$ levels, the time to subcutaneous insulin therapy via the resolution of ketosis/ketoacidosis was $16.89 \mathrm{~h}$ in patients with a mean $25(\mathrm{OH})$ D level of $<20 \mathrm{ng} / \mathrm{mL}$. By comparison, this parameter was 11.03 $h$ in patients with a mean $25(\mathrm{OH}) \mathrm{D}$ level of $>20 \mathrm{ng} / \mathrm{mL}$. The time to resolution of ketosis/ketoacidosis was significantly longer in patients with a mean $25(\mathrm{OH}) \mathrm{D}$ level of $<20 \mathrm{ng} / \mathrm{mL}(\mathrm{p}=0.020)$. Additionally, insulin doses at discharge were significantly lower in patients with a mean $25(\mathrm{OH}) \mathrm{D}$ level of $10-20 \mathrm{ng} / \mathrm{mL}(\mathrm{p}=0.039)$.

\section{DISCUSSION}

Although sunlight is a major source of vitamin D, individual factors, genetic variation and environmental factors may alter vitamin D levels. Blood 25(OH)D level represents the stored vitamin $D$ from cutaneous synthesis and dietary intake (11). However, no consensus has been obtained on deficient or sufficient vitamin $D$ levels. Different studies have revealed varying threshold levels. For instance, the optimal vitamin D

\section{Table 2. Clinical features at the time of diagnosis and follow-} up

Total $(n=115)$

\section{Clinical presentation at diagnosis}

DKA, $n,(\%)$

$62(53.9 \%)$

Hyperglycaemia, n, (\%)

$29(25.2 \%)$

Ketosis, n, (\%)

24 (20.9)

Time to resolution of ketosis/ketoacidosis, $h$, mean, (min-max)

$14.48 \pm 10.59$ (1-53)

Mean insulin doses at discharge, $\mathrm{U} / \mathrm{kg} /$ day, mean, (min-max)

$0.59 \pm 0.29$

(0-1.80)

Mean insulin doses in the first control visit (on month 2 \pm 1 ), $\mathrm{U} / \mathrm{kg} /$ day, mean, (min-max)

$0.55 \pm 0.27$

(0.07-1.80)

Honeymoon present, $n$, (\%)

$60(52.2 \%)$

\section{First year control}

$\mathrm{HbA1c}$ \%, mean, (min-max)

$10.26 \pm 2.51$ (5.50-15.90)

Insulin dose, U/kg/day, mean, (min-max)

$0.56 \pm 0.24$

(0.00-1.44)

\section{Second year control}

$\mathrm{HbA} 1 \mathrm{c}, \%$, mean, (min-max)

$7.03 \pm 1.17$

(5.20-12.90)

Insulin dose, U/kg/day, mean, (min-max)

$0.67 \pm 0.24$

(0.00-1.33)

25(OH)D: 25-hydroxyvitamin D, DKA: diabetic ketoacidosis, min: minimum, max: maximum level in children is $20 \mathrm{ng} / \mathrm{mL}$ (3). Furthermore, regional and geographic variations have been found in studies evaluating vitamin D levels in patients with T1DM. In a study on 88 patients with newly diagnosed T1DM, Pozzilli et al. (12) found that the mean $1,25(\mathrm{OH}) \mathrm{D}$ level in diabetic patients is lower than that in the controls. They also observed that vitamin D level had no correlation with age, gender, season at diagnosis and $\mathrm{HbA} 1 \mathrm{c}$ levels. In a diabetes incidence study in Sweden, Littorin et al. (13) observed that mean 25(OH)D levels at presentation and on year 8 are significantly lower in 459 patients with T1DM than in the controls. In our study, the majority of the patients with T1DM had deficient/insufficient mean 25(OH)D levels when the groups were compared on the basis of their vitamin $D$ levels. The mean 25(OH)D levels were $<30$ and $<20 \mathrm{ng} / \mathrm{mL}$ in $86 \%$ and $60 \%$ of the patients, respectively. In addition, the mean $25(\mathrm{OH})$ D levels were $<20$ and $<10 \mathrm{ng} / \mathrm{mL}$ in $70.9 \%$ and $30.7 \%$ of the girls, respectively. The mean $25(\mathrm{OH}) \mathrm{D}$ level was lower in girls than in boys. Furthermore, vitamin D deficiency/insufficiency was more common in the former than in the latter. Consistent with previous findings, our results revealed that low vitamin $D$ levels in this age group might be due to poor dietary habits in the adolescence period and the accelerated growth rate in puberty. Consequently, their vitamin D requirement increased.

Several studies on the relationship between acidosis and vitamin $D$ have suggested that a sufficient vitamin $D$ level protects against DKA, particularly in cases induced by infection (14). Studies have also demonstrated that chronic metabolic acidosis decreases 1-alpha-hydroxylase levels, thereby transforming $25(\mathrm{OH}) \mathrm{D}$ to $1,25(\mathrm{OH}) \mathrm{D}$; by contrast, other studies have shown that chronic metabolic acidosis increases 1,25(OH)D levels $(15,16)$. In an Italian study on 58 patients with T1DM, 25(OH)D level is lower in the patient group than in the controls; furthermore, vitamin $D$ levels are lower in patients presenting with ketoacidosis than in patients without ketoacidosis (17). In our study, the mean $25(\mathrm{OH})$ D level was significantly higher in 17 cases with mild ketoacidosis than in cases with moderate or severe ketoacidosis. According to vitamin $D$ deficiency/insufficiency/sufficiency, the time to subcutaneous insulin therapy through the resolution of ketosis/ ketoacidosis was significantly longer in patients with a mean $25(\mathrm{OH}) \mathrm{D}$ level of $<20 \mathrm{ng} / \mathrm{mL}$. This finding suggested that $25(\mathrm{OH})$ $D$ levels could be associated with ketoacidosis at presentation, and 25(OH)D levels might affect insulin synthesis and secretion mechanisms. Therefore, vitamin D levels likely influenced data at presentation, but they did not affect the subsequent process. However, further studies with a larger sample size should be conducted.

Aljabri et al. (18) investigated the effects of vitamin $D$ replacement on patients with T1DM and vitamin D deficiency. They gave vitamin $D$ and calcium supplement to patients with vitamin $\mathrm{D}$ deficiency and assessed the mean $\mathrm{HbA} 1 \mathrm{c}$ and $25(\mathrm{OH})$ $\mathrm{D}$ levels after 12 weeks. They found that vitamin D positively affects the metabolic control of patients with diabetes. Similarly, Svoren et al. (19) and Giri et al. (20) observed that 


\begin{tabular}{|c|c|c|c|c|}
\hline $\begin{array}{l}\text { Total } \\
(n=115)\end{array}$ & $\begin{array}{l}\text { Deficient }(\mathrm{n}=69) \\
<20 \mathrm{ng} / \mathrm{mL}\end{array}$ & $\begin{array}{l}\text { Insufficient }(\mathrm{n}=30) \\
20-30 \mathrm{ng} / \mathrm{mL}\end{array}$ & $\begin{array}{l}\text { Sufficient }(\mathrm{n}=16) \\
>30 \mathrm{ng} / \mathrm{mL}\end{array}$ & $\mathrm{p}$ value \\
\hline 25(OH)D, ng/mL, mean, (min-max) & $\begin{array}{l}11.97 \pm 4.04 \\
(3.00-19.30)\end{array}$ & $\begin{array}{l}23.85 \pm 2.89 \\
(20.20-29.70)\end{array}$ & $\begin{array}{l}39.52 \pm 10.90 \\
(30.50-61.00)\end{array}$ & $0.001^{*}$ \\
\hline $\begin{array}{l}\text { Time to the resolution of ketosis/ketoacidosis, } h \text {, mean, (min- } \\
\max \text { ) }\end{array}$ & $\begin{array}{l}16.89 \pm 11.47 \\
(4-53)\end{array}$ & $\begin{array}{l}9.70 \pm 5.99 \\
(1-20)\end{array}$ & $\begin{array}{l}13.21 \pm 10.71 \\
(3-36)\end{array}$ & $0.020^{\star}$ \\
\hline $\begin{array}{l}\text { Insulin doses at first control visit (on month } 2 \pm 1 \text { ), U/kg/day, } \\
\text { mean, (min-max) }\end{array}$ & $\begin{array}{l}0.52 \pm 0.26 \\
(0.07-1.31)\end{array}$ & $\begin{array}{l}0.54 \pm 0.23 \\
(0.24-1.22)\end{array}$ & $\begin{array}{l}0.68 \pm 0.37 \\
(0.19-1.80)\end{array}$ & 0.104 \\
\hline Honeymoon present & 37 (543.47\%) & $18(60 \%)$ & $5(31.2 \%)$ & \multirow{2}{*}{0.162} \\
\hline Honeymoon absence & $312(456.63 \%)$ & $12(40 \%)$ & $11(68.8 \%)$ & \\
\hline Poor (>9\%) & $40(58 \%)$ & $21(70 \%)$ & $8(50 \%)$ & 0.693 \\
\hline \multicolumn{5}{|l|}{$\mathrm{HbA} 1 \mathrm{c}$ at year $2, \mathrm{n},(\%)$} \\
\hline Good (<7.5\%) & 49 (721.10\%) & 24 (820.80\%) & 9 (6056.3\%) & \multirow{3}{*}{0.329} \\
\hline Moderate (7.5-9\%) & $167(234.56 \%)$ & $45(136.86 \%)$ & $56(337.35 \%)$ & \\
\hline Poor (>9\%) & $3(4.4 \%)$ & $1(3.4 \%)$ & $1(6.72 \%)$ & \\
\hline Insulin dose at year 1, U/kg/day, mean, (min-max) & $\begin{array}{l}0.53 \pm 0.24 \\
(0.00-0.17)\end{array}$ & $\begin{array}{l}0.48 \pm 0.66 \\
(0.25-1.27)\end{array}$ & $\begin{array}{l}0.53 \pm 0.82 \\
(0.32-1.44)\end{array}$ & 0.118 \\
\hline Insulin dose at year 2, U/kg/day, mean, (min-max) & $\begin{array}{l}0.66 \pm 0.27 \\
(0.00-1.24)\end{array}$ & $\begin{array}{l}0.69 \pm 0.24 \\
(0.27-1.33)\end{array}$ & $\begin{array}{l}0.66 \pm 0.14 \\
(0.47-0.97)\end{array}$ & 0.871 \\
\hline
\end{tabular}

\section{Table 4. Relationship of 25-hydroxyvitamin D levels with} ketoacidosis

\begin{tabular}{|c|c|c|}
\hline \multicolumn{2}{|c|}{$\begin{array}{l}\text { Mean } 25(\mathrm{OH}) \mathrm{D} \text { level according to acidosis severity, } \\
\mathrm{ng} / \mathrm{mL} \text {, (min-max) }\end{array}$} & $p$ value \\
\hline Mild acidosis $(n=17)$ & $\begin{array}{l}24.45 \pm 11.58 \\
(7.40-60.00)\end{array}$ & \multirow{3}{*}{$0.020^{*}$} \\
\hline Moderate acidosis $(n=21)$ & $\begin{array}{l}16.11 \pm 7.74 \\
(3.00-39.20)\end{array}$ & \\
\hline Severe acidosis $(n=24)$ & $\begin{array}{l}16.18 \pm 10.72 \\
(4.90-51.00)\end{array}$ & \\
\hline
\end{tabular}

$25(\mathrm{OH}) \mathrm{D}$ deficiency is associated with poor metabolic control. In our study, $60 \%$ of the patients had poor metabolic control, as indicated by their mean $\mathrm{HbA} 1 \mathrm{c}$ level in the $1^{\text {st }}$ year. Conversely, $71.3 \%$ of the patients had good metabolic control, as shown by their mean $\mathrm{HbA} 1 \mathrm{c}$ level in the $2^{\text {nd }}$ year. According to vitamin $D$ deficiency, insufficiency and sufficiency, mean $\mathrm{HbA} 1 \mathrm{c}$ levels and metabolic control were comparable in our study. Although glycaemic control following vitamin D replacement could not be addressed because of our retrospective study design, our data suggested that vitamin D could regulate glycaemic control because of its protective features and positive effects on beta cell function and insulin sensitivity.

\section{Study Limitations}

Our study had some limitations. Firstly, this study was retrospective and had relatively few patients. We could not assess the exact effect of vitamin $D$ replacement therapy on clinical outcomes because vitamin $D$ treatment could be affected by a number of factors, such as patient compliance, season, baseline vitamin D level and dietary intake. Secondly, the follow-up period might not be long enough. Lastly, a control group consisting of healthy children in the same age group was lacking.

\section{CONCLUSION}

This pilot study assessed the 25(OH)D levels at the time of diagnosis in the context of the clinical, laboratory and followup data of patients with T1DM. We found that vitamin D levels affected the severity of clinical presentation, time to the resolution of ketoacidosis and insulin doses at discharge, but these levels had no effect on follow-up data. However, the measurement of vitamin $\mathrm{D}$ levels at the time of diagnosis and replacement therapy might contribute to the honeymoon status of $52.2 \%$ of the patients in their control visit on month $2 \pm 1$. As such, prospective studies on this topic should be further performed.

Ethics Committee Approval: Dr. Sami Ulus Gynecology Obstetrics and Child Health and Diseases Training and Research Hospital Ethics Committee ethical approval was obtained for the retrospective review 
of the cohort of patients diagnosed with T1DM (approval number: 2016/73799008).

Informed Consent: Retrospective study.

Peer-review: Externally peer-reviewed.

Author Contributions: Surgical and Medical Practices - G.K., A.A.Y.; Concept - G.K., Z.A., Ş.S.E., S.Ç.; Design - G.K., Z.A., Ş.S.E., S.Ç.; Data Collection and/or Processing - G.K., A.A.Y.; Analysis and/or Interpretation - G.K., S.Ç.; Literature Search - G.K., A.A.Y., S.Ç.; Writing - G.K., S.Ç.

Conflict of Interest: The authors have no conflict of interest to declare.

Financial Disclosure: The authors declared that this study has received no financial support.

\section{REFERENCES}

1. Atkinson MA, Maclaren NK. The pathogenesis of insulin-dependent diabetes mellitus. N Engl J Med 1994; 331: 1428-36.

2. Dahlquist GG, Patterson C, Soltesz G. Perinatal risk factors for childhood type 1 diabetes in Europe. The EURODIAB Substudy 2 Study Group. Diabetes Care 1999; 22: 1698-702.

3. Zella JB, DeLuca HF. Vitamin D and autoimmune diabetes. J Cell Biochem 2003; 88: 216-22.

4. Gregori S, Giarratana N, Smiroldo S, Uskovic M, Adorini L. A 1alpha 25 dihydroxyvitamin D (3) analog enhances regulatory T-cells and arrests autoimmune diabetes in NOD mice. Diabetes 2002; 51: 1367-74.

5. Dunger DB, Sperling MA, Acerini CL, Bohn DJ, Daneman D, Danne TPA, et al. ESPE/LWPES consensus statement on diabetic ketoacidosis in children and adolescents. Arch Dis Child 2004; 89: 188-94.

6. Chase HP, Garg SK, Jelley DH. Diabetic ketoacidosis in children and the role of outpatient management. Pediatr Rev 1990; 11: 297-304.

7. Rosenbauer J, Dost A, Karges B, Hungele A, Stahl A, Bächle C, et al. Improved metabolic control in children and adolescents with type 1 diabetes. Diabetes Care 2012; 35: 80-6.

8. Abacı A, Böber E, Büyükgebiz A. Type 1 diabetes. Current Pediatrics 2007; 5: 1-10.

9. Holick MF, Binkley NC, Bischoff-Ferrari HA, Gordon CM, Hanley DA, Heaney RP, et al. Evaluation, treatment, and prevention of vitamin D deficiency: an Endocrine Society clinical practice guideline. J Clin Endocrinol Metab 2011; 96: 1911-30.
10. Holick MF. Vitamin D: extraskeletal health. Rheum Dis Clin North Am 2012; 38:141-60.

11. Zerwekh JE. The measurement of vitamin D: analytical aspects. Ann Clin Biochem 2004; 41: 272-81.

12. Pozzilli P, Manfrini S, Crinò A, Picardi A, Leomanni C, Cherubini V, et al. Low levels of 25-hydroxyvitamin D3 and 1,25-dihydroxyvitamin D3 in patients with newly diagnosed type 1 diabetes. Horm Metab Res 2005; 37: 680-3.

13. Littorin B, Blom P, Schölin A, Arnqvist HJ, Blohmé G, Bolinder J, et al. Lower levels of plasma 25-hydroxyvitamin D among young adults at diagnosis of autoimmune type 1 diabetes compared with control subjects: results from the nationwide Diabetes Incidence Study in Sweden (DISS). Diabetologia 2006; 49: 2847-52.

14. Grant WB. Hypothesis--ultraviolet-B irradiance and vitamin D reduce the risk of viral infections and thus their sequelae, including autoimmune diseases and some cancers. Photochem Photobiol 2008; 84: 356-65.

15. Kraut JA, Gordon EM, Ransom JC, Horst R, Slatopolsky E, Coburn JW et al. Effect of chronic metabolic acidosis on vitamin $D$ metabolism in humans. Kidney Int 1983; 24: 644-8.

16. Kraph R, Vetsch R, Vetsch W, Hulter HN. Chronic metabolic acidosis increases the serum concentration of 1,25-dihydroxyvitamin $D$ in humans by stimulating its production rate. Critical role of acidosis-induced renal hypophosphatemia. J Clin Invest 1992; 90: 2456-63.

17. Franchi B, Piazza M, Sandri M, Mazzei F, Maffeis C, Boner AL. Vitamin D at the onset of type 1diabetes in Italian children. Eur J Pediatr 2014; 173: 477-82.

18. Aljabri KS, Bokhari SA, Khan MJ. Glycemic changes after vitamin D supplementation in patients with type 1 diabetes mellitus and vitamin D deficiency. Ann Saudi Med 2010; 30:454-8.

19. Svoren BM, Volkening LK, Wood JR, Laffel LM. Significant vitamin D deficiency in youth with type 1 diabetes Mellitus. J Pediatr 2009; 154: 132-4.

20. Giri D, Pintus D, Burnside G, Ghatak A, Mehta F, Paul P, et al. Treating vitamin $D$ deficiency in children with type I diabetes could improve their glycaemic control. BMC Res Notes 2017; 10: 46. 